\title{
Ольга ГАЙДАМАЧУК
}

\section{ДЕТОНАЦІЯ ЯК ГРАМАТОЛОГІЧНА ВЕРСІЯ ЧИТАННЯ ФІЛОСОФСЬКИХ TEKCTIB}

«Проблема читання - це нині передній край науки саме тому, що ми зараз знаходимося у підвішеному стані (suspens) між двома епохами письма... Ми маємо вчитися інакше читати»

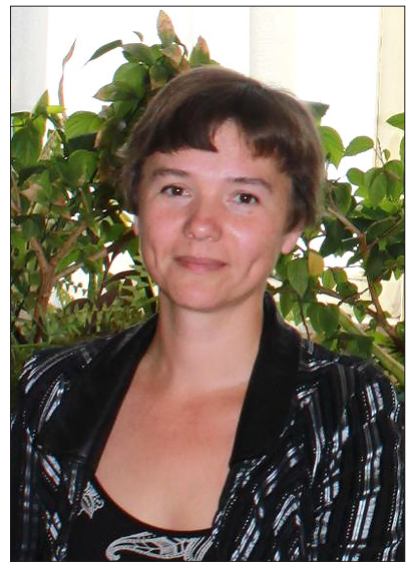

\section{Ж.Дерріда «Про граматологію»}

Граматологічна версія читання філософських текстів (тлумачимо ї як детонацію) екстраполюється на сучасні освітні підходи. Пропонується осмислення різниці між методикою, націленою на лідерську роль лектора (teacher-centered strategy) та методикою, зорієнтованою на особистість студента (learner-centered strategy). Деконструктор ревокує «логоцентричну» інтонацію (відхиляє субординацію - зосередженість на голосі лектораексперта як єдиного джерела сенсу) на користь «граматологічної» артикуляції. Фактично деконструкція дає голос замовчаним детонаціям. Максимальне розосередження дозволяє визнати студентів рівноправними джерелами сенсу, що в західно-європейському освітньому дискурсі називається особистісно-орієнтованим підходом. Стратегія деконструкції розкладена на три тактичних кроки: 1) традиційне інтонування відкриває філософію; 2) «призупинка» інтонації задля де-тонування проінтонованого (помилка як позитивна цінність); а 3) артикуляція як довершена техніка одночасного зчитування ін- $i$ де-тонацій в їхній взаємнообумовленій повноті має відкривати все поле тонації. Модель «без домінацї̈» сприяє «справедливій грі»: інструктор, утримуючись від командної ролі, як рівноправний учасник навчального процесу сам стає учнем нарівні зі студентами, здобуваючи знання щзоразу в інший спосіб.

Ключові слова: особистісно-зорієнтований метод, детонація, інтонація, артикуляція, деконструкція, читання.

Для людини, яка занурюється в світ філософії, рано чи пізно актуалізується проблема читання філософських текстів, тим більше, що в філософії «читати і писати не можна навчитися раз і назавжди» (Автономова, 2000: 90). А значить і лектор не може вважатися експертом 3 читання, якому вже більше нікуди рости. Різні епохи висувають свої 
вимоги до цієї навички через спрагу нових енергійних зусиль людського мозку у відповідь на нові виклики часу. Якщо минула епоха віддавала перевагу навчальній стратегії, головним діючим суб’єктом якої був учитель (викладач, професор, ментор або «всезнайко» ${ }^{1}$ тощо) як взірець чи експерт (teacher-centered strategy), тобто людина вже освічена, яка ширить свій власний досвід читання і веде за собою. То сучасні тенденції в західно-європейській освіті свідчать про те, що ця стратегія визнана не надто ефективною і натомість потужно просувається і апробується стратегія навчання, головним суб'єктом якої стає ученьстудент (learner-centered strategy ${ }^{2}$ ). Причому мається на увазі не один (наприклад, найсильніший учень), а кожен окремий учень як такий, незалежно від його здібностей, ритму роботи чи темпераменту. Практика показала, що такий підхід набагато ефективніший, бо заохочує студентів до активного, а не пасивного засвоєння знань, внаслідок чого неймовірно зростає і якість здобутої освіти. Як це пов’язано зі стратегіями читання?

Проблема читання, про поточне метафілософське загострення якої так чітко написав французький філософ Жак Дерріда у своїй роботі «Про граматологію» ${ }^{3}$ - зовсім не випадкова для наразі безпрецедентного зламу двох епох письма: минулого логоцентризму (з його teacher-centered strategy) і майбутньої граматології (суголосної з learner-centered strategy). Однак, незважаючи на те, що ця книга перебувала і перебуває у фокусі ${ }^{4}$ уваги багатьох дослідників ${ }^{5}$ (зокрема, i

\footnotetext{
${ }^{1}$ Термін «всезнайко» взято з рецензії Д.Шевчука Універсальний метод учителянезнайка, або емансипація через навчання на книгу: Рансьєр Ж. Учитель-незнайко. П’ять уроків із розкріпачення розуму (Шевчук, 2013).

2 Луїз Старкі, наприклад, інтерпретує цей термін як концептуальний синтез трьох вимірів: людського / humanistic (кожен учень - унікальна істота); діячевого /agentic (уповноважувати учнів на діï); пізнавального / cognitive (відстежувати навчальний прогрес кожного учня) (Starkey, 2017: 1.). У вітчизняному науковому дискурсі цей термін перекладається як «особистісно-зорієнтований підхід» (Лук'яненко, 2016).

${ }^{3}$ О. Гурко пропонує уточнений переклад цієї назви: «Дещо з того, що стосується (відноситься до) граматології» (Гурко, 2001: 60).

${ }^{4}$ Г. П. Хендрікс тлумачить деконструкцію як «подвійне читання», «близьке читання, хоча й у негативний спосіб» (Hendricks, 2016: P.2).

${ }^{5}$ В.Кірбі доводить актуальність запропонованої Дерріда термінології («слід», «грама», «письмо») для вирішення сучасних проблем (Vicky Kirby, 2016: 47); Н. Еpтюрк використовує граматологію для постструктуралістського аналізу турецької літератури (N. Ertürk, 2011); М.Г. Кохановська вважає деконструкцію ефективною у подоланні ієрархізації задля справедливості (Кохановська, 2016); Л.А.Звєздін аналізує граматологічне викреслення як особливий пунктуаційний знак у практиці фіксації сенсу (Звездин, 2015: 44) тощо.
} 
стратегій читання ${ }^{1}$ ), ми виявили один аспект, який з невідомих причин залишився поза дослідницькою увагою, а саме: програмна налаштованість деконструкції на детонацію: «не розвалювання, а підривання, де-конструкцію всіх тих значень, джерелом яких був логос» (Деррида, 2000: 124). Отже, Дерріда прагне оптимізувати «енергопостачання» філософського прочитання через «підключення» альтернативних джерел сенсу, оскільки, як виявилося у процесі деконструкції, таких джерел багато (зокрема, у цій статті ми говоритимемо про артикуляцію, тонацію та детонацію), а логос - тільки один з них. Досі будучи монополістом, логос (з інтонацією як рушійною силою) спромігся засліпити (і заглушити) інші доступні джерела (монолог лектора передбачає мовчазне слухання студентів; інколи з правом поставити запитання). Дерріда, який розгорнув свою антимонопольну стратегію просування письма, оголошує рушійною силою артикуляцію (коли «замовчана» інтонація тексту змушує читача користуватися власним голосом, щоб здобути сенс, переходячи від пасивного сприйняття до активного творення значень).

Яку місію деконструктор покладає на артикуляцію? - Розпізнати це засліплення / заглушення, щоб спромогтися його «призупинити» / «відтермінувати», оскільки, що важливо, «письмо зовсім не редукує голос як такий, а тільки включає його в свою систему» (Деррида, 2000: 229). Іншими словами, інтонація (і логос), які позбавляються «командної ролі» ${ }^{2}$, включаються в систему письма на рівних умовах з рештою джерел сенсу. А значить, позбавлений «командної ролі» голос лектора включається в поле рівноправної дискусії задля залучення до смислотворення максимального числа «джерел сенсу», тобто студентів. У цій полі-тонаційності має вироблятися якісно новий продукт.

Що все це значить для сучасної філософії освіти? Це значить, що учитель позбувається статусу лідера: тепер він не веде за собою, а на рівних з учнями супроводжує їх у навчальному процесі, створюючи умови для активної співпраці (командна і групова робота) і досягнення прак-

\footnotetext{
${ }^{1}$ О. Дронов ретельно досліджує безмежне поле значень терміну «деконструкція», один з обріїв якого він тлумачить як гіперчутливість до прихованого за буденно уживаними правилами трансляції справжнього послання: «Крізь «букву» застиглих правил деконструктивістське починання спрямоване до «духу» тієї майже неможливої значущості, що вислизає, і яка й складає «істину» текста. Адже «істина» (ефект істини) будь-якого тексту - в його власній, внутрішній деконструкції, в тій рухливості і неузгодженості, що складають саме його проблему, яка й надає йому його дієвість» (Дронов, 2009: 117).

${ }^{2}$ Читаємо у Дерріда: «...nерш ніж говорити про зникнення мовлення, треба задуматися про його нову ситуацію, про його підкорене місце в структурі, де воно більше не грає командної ролі» (Деррида, 2000: 122).
} 
тичних результатів у засвоєнні теорії. Тобто його інтонація не домінує (позбавляється командної ролі), але й не виключається з навчального процесу. Разом з тим тонаціям учнів тепер надається право на статус $i{ }^{-}$, причому детонації (право на помилку чи іншу думку) здобувають особливу вагу через визнання їх потужної навчальної сили. Детонації більше не репресуються, а навпаки - культивуються як ініціативний пошук істини поза стереотипами і потенційне джерело евристичних рішень. За рахунок такого розширення тонаційного поля, розкриваються раніше недосяжні обрії здобуття знань якісно вищого щабля не одиницями найздібніших і найсумлінніших дітей, а переважною більшістю активної аудиторії.

Дерріда демонструє, що стратегічне переінакшення в читанні має стартувати $з$ тактики перечитування вже написаного як «читання між рядків»: «мова йде... про те, щоб нарешті прочитати в цих томах те, що здавна писалося міжк рядків. Ось чому початок нелінійного письма змусило перечитати все раніше написане - але вже в іншій організаціі читання» (Деррида, 2000: 222-223). I тут прямо говориться, що цей вихід в «міжряддя», хоч і базується на лінійності, але тяжіє і виводить до нелінійності часу і тексту: «Вся ия минула епоха була влаштована як текст... А значить, вона придатна до читання... перериває лінійний час і часову лінію» (Деррида, 2000: 112). Це відштовхування від «лінії керується «спрагою» за іншими моделями читання, які, в свою чергу, мають уможливити появу інших сенсів: «”Лінія”- це лише одна з моделей» (Деррида, 2000: 221). Слово «модель» вказує нам на ту відстань, яка відділяє нас від «неможливої» істини. Натомість можливі для нас істини виробляються самими моделями. Зміна моделі - це насамперед зміна способу читання.

«Обхідні маневри» Дерріда можуть здатися стратегією «облоги»: безрезультатність прямого (лінійного) прориву до істини диктує необхідність пошуку альтернатив. Але деконструктор не відмовляється від «лінії, а просто «розосереджує» свої зусилля. Це кружляння навколо напевно убезпечує від «пастки застиглої моделі» ${ }^{1}$, але, з іншого боку, воно затягує до «пастки інерційного блукання» ${ }^{2}$ (не зупиняючись ні на чому, постійно прагнути чогось іншого). I це тримання осторонь має свої підстави, як свідчить, Л. О. Звєздін: «дистанціювання від потенційної можливості нетрадиційно провокативного впливу матеріалу з метою збереження наукової обгрунтованості дискурсу». I оскільки зміст прочитаного узалежнюється від способу прочитання, ми відчуваємо тут прямий зв'язок лінійності з інтонацією, через що остання має замішуватися

\footnotetext{
${ }^{1}$ Дерріда називає це «ефектом зацікавленого засліплення» (Деррида, 2000: 213).

2 Дерріда націлює на пошук виходу «за орбіту» смислів і значень текстової системи (Деррида, 2000: 219), а не самого тексту.
} 
«нелінійною» артикуляцією. Тут варто додати, що відсувається (відсторонюється) модель «єдино-можливого способу» читання (уособленням якої і був лектор-ментор). На їі місце пропонується альтернативна модель відкритого реєстру способів читання: скільки студентів, стільки й способів. Але, що важливо, попередня модель, залишена осторонь, відтепер має діяти як один із способів.

Саме артикуляція, згідно з інтуїцією Дерріда, має тримати цю «подвійну дистанцію»: тобто, з одного боку, тримати у полі уваги «традиційну» інтонацію (як хоч і «перекреслений», але промовистий орієнтир, тобто особистий досвід читання лектора не нівелюється, а «знецінюється» до рівноправного з альтернативами), а, з іншого боку, занурюватися у детонацію, не перевищуючи лімітів виходу у ненауковість (у своєму детонуванні студенти мають триматися у полі наукового дискурсу, навіть експериментуючи з розсуванням його обріїв). А значить, йдеться про «розширення меж» інтонації за рахунок обережного залучення поки що тільки прийнятних (науковим дискурсом) детонаційних ресурсів. Це поступове «розсування меж» має синхронізуватися із запуском неквапливої «деконструкції» самого наукового дискурсу.

Таким чином, Дерріда - «людина суто письмова, навіть коли говорить» (Автономова, 2000: 63), за влучним висловом Н. Автономової, намагається ревокувати «логоцентричну» інтонацію на користь, як йому здається, «граматологічної» артикуляції. Те, що він покладає неабиякі сподівання на цього «агента» письма, здається нам безсумнівним. Найяскравіші докази цього можна знайти, по-перше, в епіграфі до підрозділу «Тріщина» ${ }^{1}$. Там цитуються слова з листа Роже Лапорта, де на запит деконструктора пропонується слово, у значенні якого поєднуються відмінність і артикуляція: «Мабуть, вам хотілося знайти таке слово, яке позначало б і відмінність, і артикуляцію, членоподільність...» (Деррида, 2000: 192). По-друге, «Про граматологію» містить окремий підрозділ під назвою «Артикуляція»² (Деррида, 2000: 403-451). Крім того, частотність уживання цього слова (articulation) в оригінальному тексті складає близько 100 випадків. Зокрема, можна прочитати таке: «Артикуляція $\epsilon$ становлення мови як письма» (Деррида, 2000: 402) або таке: «відмінність, первісна членоподільність скасовує археологію» (Деррида, 2000: 403). Отже, саме до дій артикуляції дослухається Дерріда у своєму прагненні читати інакше, тобто «призупиняючи інтонування» (як своє влас-

${ }^{1}$ Третій підрозділ другої глави «Лінгвістика і граматологія» першої частини «Письмо до письма».

${ }^{2}$ Н.Автономова перекладає його як «Членоподільність». Це третій підрозділ (який, до речі, має ще п’ять своїх структурних частинок) третьої глави «Генеза і структура «Есе про походження мов»» другої частини «Природа, культура, письмо») 
не, так і «авторське»). I саме ця призупинка називається розрізнЯння (diffйrAnce): це «економія» відтермінування і водночас відсторонення» (diffŭrer)» (Деррида, 2000: 140). I тут ми спробуємо окреслити різницю між нашими ключовими термінами: 1) тонація / тональність ${ }^{1}$ позначає нерозрізнювану сукупність усіх потенційних $i н$ - і дe-тонацій певного тексту; тоді як 2) iн-тонація позначає виокремлену (як «правильну») 3 цієї сукупності певну тонацію, що відбувається через певний спосіб прочитання і тільки на час цього прочитання; що ж до 3) де-тонацій, то це решта тонацій цієї сукупності, що лишилися після добору інтонації; i, нарешті, 4) артикуляція позначає сам цей процес розмежування $і$ - і де- в тонаціях. Отже, Дерріда пропонує сфокусуватися на останньому, прагнучи «однакових правил гри» для всіх джерел сенсу. Але нам здається, що момент «справедливої гри» співвідносний тільки з тонацією до процесу артикуляційної проробки. На практиці максимум, на який можна сподіватися, - це політонація, коли якнайбільша кількість тонацій мирно співіснує без претензій на першість.

Ситуація навчальної ситуації, коли тонація кожного учня сприймається в статусі $і$-, вимагає кардинального перегляду системи оцінювання, оскільки вчителеве $і н$ - більше не може виконувати роль взірця, так само як переймати на себе одноосібне оцінювання. За новими - тонаційними правилами - всі функції «ментора» мають бути рівномірно розподілені між учасниками навчального процесу.

Чим так завинила інтонація? - Здається, що для деконструктора вона є уособленням «диктуючого тону» (інакше кажучи, логоцентризму), який, виокремлюючи один-єдиний «правильний» сенс, нібито позбавляє голосу (тим, що заглушує їх: «...фонологізм, гучний голос якого заллушує письмо...» (Деррида, 2000: 243)) решту альтернативних інтерпретацій (які, як ми щойно з'ясували, в цей момент перетворюються на де-тонації). Отже, деконструктор прагне відстрочувати дію інтонації, нібито стаючи на бік цих безголосих тонацій («нульовий ступінь», (Деррида, 2000: 259)). Це відповідає логіці палеонімії², якої, згідно з О.Гурко, він намагається дотримуватися. А значить, дія артикуляції має тривати безупинно. I правда в тому, що поки що ми не готові мати справу з тонацією як такою.

\footnotetext{
${ }^{1}$ О.Бурова пише про «тональність людини-суб'єкта» у процесі мислення (Бурова, 2009: 85). Чи не є сама ця «тональність» передумовою здатності мислити?

${ }^{2}$ Тут мається на увазі уживання старих понять у нових значеннях: колишній зміст відсторонюється, а новий - прищеплюється (Гурко, 2001: 74). Ця процедура, власне, і є «відстороненням» інтонації на користь детонацій. Більше того, ця «прищепа» постійно трансгресується, через що «нові» тонації, щойно здобувши статус $i H-$, знову «відсторонюються» через установку уникати фіксації.
} 
Якби ми справді відстрочили дію інтонації (а значить, і утрималися від артикуляції), то стикнулися б з полем непомежованої, нерозчленованої тонації тексту, будь-яке $i н$ - котрої наперед завжди вже було би скасовано. Але фактично деконструкція дає голос саме детонаціям (тобто $з$ визначеною, але «замовчаною» інтонацією), які за інших умов навряд чи здобули б на нього право. I саме тому ми розуміємо це як презентацію детонаційної стратегії читання, хоча, за іронією, у власному тексті Дерріда з-поміж рядків не розчув голос цієї думки.

Тепер, щоб не бути голослівними, розберемо кілька прикладів з тексту «Про граматологію». Нас цікавлять ці три стратегії в дії: інтонаціядетонація-артикуляція. Отже, по-перше, автор «Про Граматологію», деконструюючи $^{1}$ перечитувані ним тексти, відштовхувався від наявної $i н$-тонації (на яку нібито була налаштована вся «лого-фоно-центрична» епоха). Ми проілюструємо увагу Дерріда до 1) власної інтонації, до 2) камер-тону тексту, який він читає, і до 3) інтонації тексту, який він деконструює.

1. Власна інтонація. Дерріда використовує ресурс власної інтонації саме в іiї командній ролі, коли через курсив скеровує увагу читача: «Bиділені курсивом місия мають певним чином спрямовувати читання цього тексту й інших подібних текстів» (Деррида, 2000: 365). Уживання курсиву з такою метою свідчить про те, що деконструктор послуговується розширеним інструментарієм інтонаційних засобів письма.

2. Камер-тон. Зовсім не випадково Дерріда дає емоційну характеристику камертону тексту Руссо («постійна тривога»), хоча й робить це 3 інтонацією непевності («здається»): «Здається, що роздуми Руссо просякнуті постійною тривогою $і$ від цього в них така сила...» (Деррида, 2000: 359). Сила цієї тривоги передалася Дерріда через текст, через інтонаційні засоби тексту. І він сприймає іiї, на неї зважає і реагує, що ще раз доводить нескасованість інтонування у деконструкції.

3. Інтонації чужого тексту. Дерріда з'ясовує, що «письмо “іншого" щоразу виявляється обтяженим своїми власними схемами» (Деррида, 2000: 214). Під час деконструкції тексту Руссо «Есе про походження мов...» він зіставляє «описи» Руссо з його ж «заявами» (Деррида, 2000: 389), причому здебільшого це - випадки протиріччя описів - заявам і навпаки. Наприклад: «Руссо відкрито заявляє про те, що він хоче сказати, а саме що членоподільність і письмо - це не первісна хвороба мови...» (курсив

${ }^{1}$ Дерріда, наприклад, розрізняє поверхню і глибину текста Руссо, що дозволяє йому «знімати» поверхневі протиріччя через заглиблення «в його буквальний сенс». Але це заглиблення він здійснює тільки після «нейтралізації» (Деррида, 2000: 484) поверхневого шару тексту. Отже, здається, що інтонація для Дерріда не більше ніж ефект поверхні тексту. 
Деррида, 2000: 402). I в даному випадку йдеться саме про інтонацію заяви (про розставлені Руссо емоційні й логічні акценти, згідно з його намірами), яку Дерріда зчитує, щоб далі «позбавити іï голосу» - і розчути «справжній опис». І це - наступна стратегія.

Отже, по-друге, «нейтралізувавши» інтонацію заяви, Дерріда прагне витлумачити раніше нерозчуті де-тонації (у даному випадку це - опис, який через протиріччя заявленому підриває його значення). Наприклад, продовжуючи читати перервану вище цитату, маємо: «...але при цьому він описує те, що зовсім не хотів би говорити, а саме що артикуляція, членоподільність і сам простір письма існують у мові від початку» (курсив Деррида, 2000: 402). Саме тут Дерріда озвучує ті «нечувані» детонації, які «підривають» вище вказані інтонації Руссо. Що характерно, «авторство» інтонацій і детонацій Дерріда однаково приписує Руссо, зіставляючи їх як поверхню з глибиною. В такий спосіб він залишається «в полі» тексту Руссо (деконструює його зсередини), а не за його межами (не ззовні).

По-третє, ми мали б перейти до балансування у полі тонації. Проте фокус Дерріда - саме детонації (розсіювання, розпорошення, підрив тощо $\left.{ }^{1}\right)$, тому далі він не йде. Він пояснює, що деконструкція не потребує зовнішніх структур для того, щоб здійснюватися зсередини: всі потрібні ій детонаційні засоби вона запозичує у тієї структури, яку намагається підірвати (Деррида, 2000: 141). Найулюбленіший детонаційний засіб у Дерріда - це лапки ${ }^{2}$, основна функція яких вказувати на фундаментальний для деконструкції жест «викреслення» (Деррида, 2000: 172, 186-187, 194, 223, 250). В. Россман інтерпретує цей пунктуаційний знак як конвоїрів: «світ постає у деконструкції під суворим конвоєм лапок» В «епохальному режимі лапок». (Россман, 2003: 74). Але, з іншого боку, граматологічні лапки можна сприймати як примноження (несанкціонованих автором?) «входів» (дверей) до простору тексту. Однак і «традиційний» детонаційний засіб філософії - ставити під сумнів (знак питання) твердження - теж активно використовується. Як наслідок, у його власному тексті активізуються «детонаційні процеси».

3 цього випливає висновок, що нова стратегія читання Дерріда розкладена на три тактичних кроки, два з яких він спромігся здійснити сам і вказати нам, а третій тільки інтуїтивно «промацав», запросивши нас зробити його самотужки:

\footnotetext{
${ }^{1}$ Його цікавить «розрив» між «буттям і словом, між сенсом і голосом», який хоч і «полонений метафізикою, але рветься на волю» (Деррида, 2000: 138).

${ }^{2}$ В.Россман коментує це так: «лапки - єдиний знак, який залишається вірним «письму» $i$ графізму в иілому (решта знаків відверто протягують в письмо елементи усного мовлення і є його агентами)» (Россман, 2003: 73-74).
} 
1) перший крок пролягає через інтонування, оминувши який, ви не здобудете орієнтирів для наступних двох кроків. Філософія (метафізика) відкривається через традиційну «інтоно-логічну» (тобто логоцентричну) стратегію читання;

2) другий крок пролягає через «призупинку» інтонаційного диктату задля де-тонування проінтонованого, тобто задля посиленого прослухування безголосих тем, міжрядкових сенсів і решти хаосмічного шуму;

3) третій крок вчувається через артикуляцію як довершену техніку одночасного зчитування $і н$ - і де-тонацій в їхній взаємообумовленій повноті, яка відкриває все поле тонації під вашу особисту відповідальність.

Припустімо, що в моделі «без домінації» (як того, хто навчає, так і того, кого навчають) і має проявлятися ситуація «справедливої гри» ${ }^{1}$. Що це значить на практиці? Це значить, що інструктор, утримуючись від командної ролі, тільки тоді буде «рівноправним учасником» навчального процесу, коли він сам стане учнем нарівні з рештою студентів. Йдеться про ситуацію, коли знання треба буде здобувати щоразу в інший спосіб - ходити неходженими стежками, полем тексту.

\section{Література:}

1. Автономова Н. Деррида и грамматология // Деррида Ж. О грамматологии: Пер. с франц. Н. Автономовой - М.: Ad Marginem, 2000. - С. 7-107.

2. Бурова О. К. Парадокс свободы картезианского cogito. Между греками и Гуссерлем // Философия языка: в границах и вне границ / науч.ред.тома С. А. Заветный. - Х.: ХНУТУСХ, 2009. - [Т. 6-7]. - С. 68-88.

3. Гурко Е. «Нечто, относящееся (относимое к) грамматологии» // Гурко Е. Деконструкция: тексты и интерпретация. Деррида Ж. Оставь это имя (Постскриптум), Как избежать разговора: денегации. - Минск: Экономпресс, 2001. - С. 60-93.

4. Деррида Ж. О грамматологии: Пер. с франц. Н. Автономовой. - M.: Ad Marginem, 2000. $-511 \mathrm{c}$.

5. Дронов А. Прагматика деконструкции: [електронний ресурс] // Топос, 2009. № 1 (21). - С. 114-119. - Режим доступу: http://ecsocman.hse.ru/data/050/976/1222/ Topos_2009_1_114-119_Dronov.pdf

6. Звездин Л. А. Подход к пониманию философской деконструкции как практики смысловой фиксации [електронний ресурс] // Вестник ЛГУ им. А.С. Пуш-

${ }^{1}$ С. О. Джанг пропонує утілити в освіті ідею «освітнього простору як осеsi (dwelling) різниці і становлення», роз'яснюючи це наступним чином: «Існування (presence) спільноти повніше, коли індивідуальні відмінності виникають (emerge); коли студенти й викладачі спроможні представляти (to present) свої унікальні відмінності, аудиторія перетворюється на простір постійного народження і зростання» (Jang, 2016: 56). 
кина. 2015. №3. - С. 44-52. - Режим доступу: http://puma/article/n/podhod-kponimaniyu-filosofskoy-dekonstruktsii-kak-praktiki-smyslovoy-fiksatsii

7. Кохановська М. Г. Деконструкція як спосіб подолання ієрархізації: [електронний ресурс] // Гілея: Науковий вісник, 2016. - Вип. 106. - С. 187 - 190. - Режим доступу: file://C:/Documents\%20and\%20Settings/Administrator/My\%20Documents/ Downloads/gileya_2016_106_50.pdf

8. Лук'яненко Л. М. Шляхи підвищення мотивації студентів, які вивчають англійську мову як основну іноземну, при навчанні говоріння в рамках особистіснозорієнтованого підходу [електронний ресурс] // Англістика та американістика. - Вип. 13, 2016. - С. 82-88. - Режим доступу: http://www.dnu.dp.ua/docs/zbirniki/ ffil/program_5817a677e65ee.pdf\#page $=82$

9. Россман В. Техники пунктуации: знак препинания как философский метод // Вопросы философии. - 2003. - № 4. - С.68-76.

10. Шевчук Д. Універсальний метод учителя-незнайка, або емансипація через навчання. Рецензія на книгу: Рансьєр Ж. Учитель-незнайко. П'ять уроків із розкріпачення розуму // Філософія освіти, 2013. - № 2 (13). - С.159-165.

11. Ertürk N. Grammatology and Literary Modernity in Turkey. New York: Oxford University Press, 2011.

12. Hendricks Gavin P. Deconstruction the end of writing: 'Everything is a text, there is nothing outside context: [електронний pecypc] // Verbum et Ecclesia. - № 37(1). - 2016. - P. 1-9. - Режим доступу: http://verbumetecclesia.org.za/index.php/VE/ article/viewFile/1509/pdf_1

13. Jang Soo Bin. Post-Structural Relational Ethics of Teacher-Student: A Theoretical Analysis of Jaques Derrida and Luce Irigaray: [електронний ресурс]. // Eurasian Journal of Social Sciences. - № 4(2). - 2016. - P. 56-65. - Режим доступу: http:// eurasianpublications.com/Eurasian-Journal-of-Social-Sciences/EJSS\%20-\%205.pdf

14. Kirby V. Grammatololgy: A Vital Science // Derrida Today. - Volume 9. - Issue 1. May, 2016. - Page 47-67.

15. Starkey L. Three dimensions of student-centred education: a framework for policy and practice [електронний ресурс] // Critical Studies in Education. Taylor \& Francis online. - January, 2017. - P. 1-16. - P. 1. - Режим доступу: http://dx.doi.org/10.1080 $/ 17508487.2017 .1281829$

\section{Ольга Гайдамачук. Детонация как грамматологическая версия чтения фи- лософских текстов \\ Грамматологическая версия чтения философских текстов (интерпре-} тируем ее как детонацию) экстраполируется на современные подходы в образовании. Предлагается осмысление разницы между методикой, нацеленной на лидерскую роль лектора (teacher-centered strategy) и методикой, ориентированной на личность студента (learner-centered strategy). Деконструктор ревоцирует «логоцентрическую» интонацию (отклоняет субординацию - сосредоточенность на голосе лектора-эксперта как единственного источника смысла) в пользу «грамматологической» артикуляции. Фактически деконструкция дает голос умолчанным детонациям. Максимальная рассредоточенность позволяет признать студентов равноправными источниками смысла, что в западноевропейском образовательном дискурсе на- 
зывается личностно-ориентированным подходом. Стратегия деконструкции разложена на три тактических шага: 1) традиционное интонирование открывает философию; 2) «приостановка» интонации для де-тонирования проинтонированного (ошибка как позитивная ценность); а 3) артикуляция как совершенная техника одновременного считывания ин- и де-тонаций в их взаимообусловленной полноте должна открывать все поле тонации. Модель «без доминации» способствует «справедливой игре»: инструктор, воздерживаясь от командной роли, как равноправный участник учебного процесса сам становится учеником наравне со студентами, добывая знания каждый раз иным способом.

Ключевые слова: личностно-ориентированный метод, детонация, интонация, артикуляция, деконструкиия, чтение.

\section{Olha Haidamachuk. Detonation as Grammatological Version of Philosophy Texts Reading}

In the article the J. Derrida's deconstruction interpretation is reasoned as a detonation. The deconstructor demonstrates that the strategic inflexion in a reading should be started from the tactics of rereading of already written as a «reading in between of lines». Derrida tries to revoke a «logocentric» intonation in favour of, as he thought, «grammatological» articulation. If it was true, we dealt with a field of unbounded, undivided tonation, the every in- of which had been always abrogated beforehand. However, in fact his deconstruction gives a voice those detonations, which will hardly have it as of right. When «Of grammatology» author was deconstructing texts he reread, he proceeded from «really obvious» intonation (there was supposed that the whole "logocentric" epoch was tuned on it), and aspired to interpret unheard before de-tonations instead of to balance in a field of tonation. It means his focal point is detonation (dispersion, scattering, burst etc.). As a result, «detonational processes» were activated in his own text too. Grammatological version of philosophy texts reading (detonation) is extrapolated on a modern learning approach. We suggest exploring the difference between the teacher-centred strategy and the learner-centred strategy. Derrida revocates «logocentric» intonation the same as he declines any subordination, which is focused mode of a lector-expertize's voice as the only source of sense, in favour of «grammatological» articulation. In fact the deconstruction gives voice to suppressed detonation. Maximum of such diffusion allows us to acknowledge students have equal rights to be sources of sense. In West-European teaching discourse it names learner-centred strategy. The conclusion is that the new Derrida's strategy of reading is divided on three tactic steps, two of which he could perform himself and showed to us, while he could only detect third one by his intuition and invited us to step there ourselves. The first step is the intoning as guiding lines obtaining for the next steps. Philosophy (metaphysics) is opened through traditional «intono-logical» (logocentric) reading strategy. The second step is «suspension» of intonation's dictat for the sake of de-tonation of the intoned (any mistake has a 
positive value. The third step is articulation as perfect techniques of simultaneous reading of in- and de-tonations in their inversely corresponding completeness, which opens the whole field of tonation. The model of the lack of domination promotes the learning situation as a «just play» for all participants: a freed from command role instructor just as one of equal-righted participants of learning process becomes the same learner as students. So every time they together should look for knowledge in the other way then before.

Keywords: learner-centered strategy, detonation, intonation, articulation, deconstruction, reading.

Гайдамачук Ольга Володимирівна - старший викладач кафедри етики, естетики та історії культури Національного технічного університету «Харківський політехнічний інститут» (НТУ «ХПІ»).

E-mail: haidamachuk@gmail.com

Haidamachuk Olha Volodymyrivna - senior lecturer of ethics, esthetics and history of culture department in NTU «KhPI», Ukraine, Kharkiv.

E-mail: haidamachuk@gmail.com 